\title{
Indirect Electrochemical Cyclisation of Bromoalkoxylated Derivatives using Environmentally Friendly Methodologies
}

\author{
E. Duñach ${ }^{\mathrm{a}}$, M. J. Medeiros ${ }^{\mathrm{b} *}$, S. Olivero ${ }^{\mathrm{a}}$ \\ ânstitut de Chimie de Nice, Université de Nice-Sophia Antipolis, CNRS, UMR 7272, \\ Parc ParcValrose, 06108 Nice Cedex 2, France \\ ${ }^{\mathrm{b}}$ Centro de Química, Universidade do Minho, Largo do Paço, 4704-553 Braga, Portugal
}

The electrochemical intramolecular cyclization of bromoalkoxylated derivatives $\underline{\mathbf{1}}$ using $\mathrm{Ni}(\mathrm{II})$ complex as mediator of electron transfer was carried out in ethanol by constant-current electrolysis in one-compartment cell in the absence of sacrificial anodes as an environmentally friendly systems.

It is demonstrated that the electroreduction reaction of bromoalkoxylated derivatives was catalyzed by the electrogenerated $\mathrm{Ni}(\mathrm{I})$ complexes. Only cyclization to the five-membered-ring esters was obtained in moderate to good yields as the main products. Functionalyzed tetrahydrofurans are important intermediates in the synthesis of natural products such as lignans.

A mechanistic scheme is proposed to explain the results obtained by means of cyclic voltammetry and constant-current electrolysis.

\section{Introduction}

The formation of carbon-carbon bonds by radical cyclisation has become a valuable synthetic tool in organic chemistry especially in the total synthesis of complex natural products $[1,2]$. Although tributyltin hydride has been a choice as the radical reducing agent in radical cyclisations its toxicity tend to limit the widespread use of these methods [1,2]. Hence, the indirect electrochemical radical cyclisation [3] catalysed by electrogenerated nickel(I) complexes has been considered as a convenient "green" alternative way to carry out such reactions. Such work has largely used aprotic organic solvents, such as $N, N^{\prime}$-dimethylformamide which presents some toxicity as a solvent.

Hence, due to environmental and health issues, the search for non-toxic fluid alternatives to such organic solvents for chemical synthesis are currently receiving attention. Electrolytic organic synthesis in non-toxic fluids would be a valuable, environmentally sound method of chemical production. In a perspective aimed at cleaner and catalytic syntheses, we have explored the intramolecular cyclisation of propargyl and allyl bromoesters catalysed by electrogenerated nickel(I) at carbon cathodes in ethanol and ethanol-water mixtures as the solvents by constant-current electrolysis in an undivided cell using a dissolving metal anodes, either $\mathrm{Mg}$, $\mathrm{Al}$ or $\mathrm{Zn}$ [4]. However, the anodic metal becomes a stoichiometric reagent rather than simply an electrode.

Thus, in order to develop an environmentally friendly methodology for radical cyclisation of bromoalkoxylated derivatives, we have investigated this reaction by indirect electrochemical methods catalysed by electrogenerated $[\mathrm{Ni}(\mathrm{tmc})]^{+}$complex in 
ethanol at constant-current electrolysis in an undivided cell using either platinum or graphite as anodes.

\section{Experimental part}

\section{Reagents}

Each of the following chemicals was used as received: nickel(II) bromide (Aldrich, 98\%), 1,4,8,11-tetramethyl-1,4,8,11-tetraazacyclotetradecane (tetramethylcyclam, tmc, Fluka, 97\%). Ethanol (EtOH), from Riedel-de-Häen, Analytical Reagent, was used as received. We purchased tetraethylammonium bromide $\left(\mathrm{Et}_{4} \mathrm{NBr}\right)$ with a purity of $98 \%$ from Fluka and tetra- $n$-butylammonium tetrafluoroborate $\left(\mathrm{Et}_{4} \mathrm{NBF}_{4}\right)$ with a purity of $99 \%$ from Aldrich. Deaeration procedures were carried out with zero-grade argon (Air Products).

All potentials are quoted with respect to a $\mathrm{Ag} / \mathrm{AgCl} / 3 \mathrm{M} \mathrm{KCl}$ in water reference electrode (-0.036 vs SCE).

\section{$\underline{\text { Cells and Instrumentation }}$}

Cyclic voltammograms were obtained with the aid of an AUTOLAB model PGSTAT12 potentiostat-galvanostat. The data from the above experiments were acquired and stored by locally written software, which controlled a data acquisition board installed in a personal computer. Cyclic voltammograms were recorded in a threeelectrode, two-compartment cell as described in earlier publications [5].

All potentials are quoted with respect to a $\mathrm{Ag} / \mathrm{AgCl} / 3 \mathrm{M} \mathrm{KCl}$ in water reference electrode (-0.036 vs SCE).

The constant-current electrolyses were carried out in a single-compartment cell (capacity $50 \mathrm{~mL}$ ), such as described in Ref. 6, with a graphite rod or platinum grid as the sacrificial anode (diameter $1 \mathrm{~cm}$ ) and a carbon felt cathode (apparent surface, $20 \mathrm{~cm}^{2}$ ) was formed into a cylinder around the counter electrode. Controlled-current electrolyses were carried out with the aid of a stabilized constant current supply (Sodilec, EDL 36.07).

${ }^{1} \mathrm{H}$ NMR data were recorded on a Varian Unity Plus 300 Spectrometer in $\mathrm{CDCl}_{3}$; $\delta$ ppm were measured versus residual peak of the solvent. Identities of the electrolysis products were confirmed by means of a Hewlett-Packard 5890 Series II gas chromatograph coupled to a Hewlett-Packard 5971 mass-selective detector.

\section{Results and discussion}

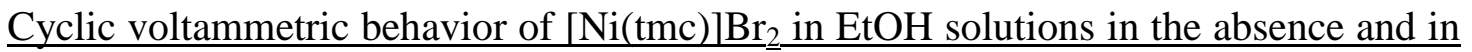
the presence of bromoalkoxylated derivatives

Cyclic voltammetry experiments showed that the $[\mathrm{Ni}(\mathrm{tmc})]^{2+} /[\mathrm{Ni}(\mathrm{tmc})]^{+}$ redox couple $(\mathrm{tmc}=$ tetramethylcyclam) gave a reversible $\mathrm{Ni}(\mathrm{II}) \mathrm{L} / \mathrm{Ni}(\mathrm{I}) \mathrm{L}$ peak in $\mathrm{EtOH}$ solutions containing $0.10 \mathrm{M} \mathrm{Et}{ }_{4} \mathrm{NBr}$. The formal electrode potential of $[\mathrm{Ni}(\mathrm{tmc})] \mathrm{Br}_{2}$ in $\mathrm{EtOH}$ occurred at $-0.86 \mathrm{~V}$ vs $\mathrm{Ag} / \mathrm{AgCl}, 3 \mathrm{M} \mathrm{KCl}$. 


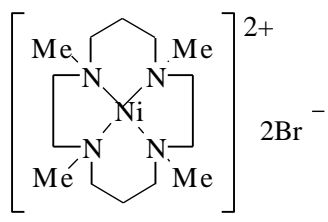

$[\mathrm{Ni}(\mathrm{tmc})] \mathrm{Br}_{2}$

After addition of bromoether $\underline{1}$ to the solution of $[\mathrm{Ni}(\mathrm{tmc})] \mathrm{Br}_{2}$ complex, the cathodic peak current, due to the formation of $[\mathrm{Ni}(\mathrm{tmc})]^{+}$complex, increases significantly and the anodic wave due to oxidation of $[\mathrm{Ni}(\mathrm{tmc})]^{+}$complex back to $[\mathrm{Ni}(\mathrm{tmc})]^{2+}$ complex is absent due to the chemical consumption of $[\mathrm{Ni}(\mathrm{tmc})]^{+}$complex. The catalytic current observed is due to the regeneration of $[\mathrm{Ni}(\mathrm{tmc})]^{2+}$ complex.

Hence, it can be established that the electron-transfer between the electrogenerated $\mathrm{Ni}(\mathrm{I})$ complex and the bromoethers $\underline{\mathbf{1}}$ occurs, followed by substrate cyclisation, according to Equations 1-3.

The data from these experiments are presented in Table 1.

Table 1. Data of the ratio $I_{c} / I_{d}$ obtained from the cyclic voltammetry experiments of $1.0 \mathrm{mM}[\mathrm{Ni}(\mathrm{tmc})] \mathrm{Br}_{2}$ complex in the presence of different concentrations of $\underline{1}$ in $\mathrm{EtOH} / 0.10 \mathrm{M} \mathrm{Et}_{4} \mathrm{NBr}$. Potential scan rate $100 \mathrm{mV} / \mathrm{s}$.

\begin{tabular}{|c|c|c|c|}
\hline \multirow{2}{*}{ Compound } & \multicolumn{3}{|c|}{$\mathbf{I}_{c} / \mathbf{I}_{d}{ }^{a}$} \\
\hline & $\gamma=2^{b}$ & $\gamma=5^{b}$ & $\gamma=10^{b}$ \\
\hline $\begin{array}{l}\text { Ethyl 2-bromo-3-(3',4'-dimethoxyphenyl)-3- } \\
\text { propargyloxy-propanoate (1a) }\end{array}$ & 2.2 & 5.1 & 9.8 \\
\hline $\begin{array}{l}\text { Ethyl 2-bromo-3-(3',4'-dimethoxyphenyl)-3- } \\
\text { (allyloxy)propanoate }(\underline{\mathbf{1 b}})\end{array}$ & 2.1 & 4.8 & 9.9 \\
\hline $\begin{array}{l}\text { Ethyl 2-bromo-3-(3',4'-methylene-dioxophenyl)- } \\
\text { 3-(propargyloxy)propanoate (1c) }\end{array}$ & 3.2 & 5.1 & 7.9 \\
\hline
\end{tabular}

From these data we can observe that the extent of the catalytic reaction increases when raising $[\mathrm{RBr}]$, for a given mediator concentration.

In the absence of $[\mathrm{Ni}(\mathrm{tmc})]^{2+}$, the bromoethers $\underline{1}$ alone gave a reduction peak at potentials below $-1.50 \mathrm{~V}$ under the same experimental conditions.

Constant-current electrolyses of $[\mathrm{Ni}(\mathrm{tmc})] \mathrm{Br}_{2}$ in the presence of bromoalkoxylated derivatives

Constant-current electrolyses of bromoalkoxylated compounds $\underline{\mathbf{1}}$ catalyzed by electrogenerated $[\mathrm{Ni}(\mathrm{tmc})]^{+}$complex was performed in a single-compartment cell using graphite or platinum instead of consumable sacrificial anodes in EtOH containing $6 \mathrm{mM}$ $\mathrm{Et}_{4} \mathrm{NBr}$ at room temperature, under an inert gas.

The $[\mathrm{Ni}(\mathrm{tmc})] \mathrm{Br}_{2}$ complex used in $10-20 \mathrm{~mol} \%$ showed an efficient catalytic activity for the electrochemical cleavage of carbon-bromine bond of substrates $\underline{\mathbf{1}}$.

Compounds $\underline{\mathbf{2}}$ (see eq. 1-3) were obtained in the different cyclisation reactions and by-products were formed in very low amounts $(<5 \%)$ and were not isolated. 
The results obtained in those experiments are summarised in Table 2.

The electroreduction of $\underline{\mathbf{1 a}}$ (Eq. 1) led to the formation of the two cyclised furan derivatives, 2-(3',4'-dimethoxy)phenyl-3-ethoxycarbonyl-4-methylene-tetrahydrofuran (2a) and its endocyclic isomer 2-(3',4'-dimethoxy)phenyl-3-ethoxycarbonyl-4-methyl2,5-dihydrofuran ( $\left.\underline{\mathbf{2} \mathbf{a}^{\prime}}\right)$ in a total yield of $91 \%$ and $\underline{\mathbf{2 a}}: \underline{\mathbf{2} \mathbf{a}^{\prime}}$ ratio of 88:12 (Table 1, entry 1).<smiles>C#CCOC(c1ccc(OC)c(OC)c1)C(Br)C(C#C)OCC#CC</smiles>

The cyclic ether $\underline{\mathbf{2 a}}$ ' was issued from a double bond isomerisation from $\underline{\mathbf{2 a}}, \underline{\mathbf{2 a}}$ being the expected primary cyclisation compound.

Next, the influence of the concentration of the catalyst was studied. It was found when the concentration of $[\mathrm{Ni}(\mathrm{tmc})]^{2+}$ complex diminished from 20 to $10 \%$ has no effect on the total yield of the cyclic compounds $\underline{\mathbf{2 a}}$ and $\underline{\mathbf{2 a}}$ ' (Table 1, entry 2). This result supports that the ratio $[\mathrm{RBr}] /[\mathrm{Ni}(\mathrm{II})]$ does not interfere on the reaction mechanism.

The electroreduction in protic media was extended to substrates $\underline{\mathbf{1 b}}$ and $\underline{\mathbf{1 c}}$. Then, the electrolysis of $\underline{\mathbf{1 b}}$ (Eq. 2) catalysed by electrogenerated $[\mathrm{Ni}(\mathrm{tmc})]^{+}$complex using a graphite/carbon fiber couple of electrodes afforded two stereoisomers of 2-(3',4'dimethoxyphenyl-3-ethoxycarbonyl-4-methyltetrahydrofuran $(\underline{\mathbf{2 b}})$ in $81 \%$ yield and a 75:25 ratio (Table 1 , entry 3 ).<smiles>C=CCOC(c1ccc(OC)c(OC)c1)C(Br)C(=O)OCC</smiles>

$\underline{1 b}$<smiles>CCOC(=O)C1C(C)COC1c1ccc(OC)c(OC)c1</smiles>

$\underline{2 b}$

The influence of the nature of the anode was next explored. The change of graphite by platinum anode in the electrolysis of $\underline{\mathbf{1 b}}$ led to the formation of $\underline{\mathbf{2 b}}$ in a yield of $73 \%$ in a stereoisomeric ratio 69:31 and of a small amount of alkene $\underline{\mathbf{3 b}}(4 \%)$ (Table 1, entry 4).

Finally, when the electrolysis of $\underline{\mathbf{1 c}}$ (Eq. 3) was performed with $\mathrm{Pt} / \mathrm{C}$ as couple electrodes, the cyclic compounds $\underline{\mathbf{2 c}}$ and $\underline{\mathbf{2 c}}$ ' were obtained in a total yield of $81 \%$ (Table 1 , entry 5).<smiles>C#CCOC(c1ccc2c(c1)OCO2)C(Br)C(=O)OCC</smiles>

$\underline{1 c}$<smiles>C=C1COC(c2ccc3c(c2)OCO3)C1C(=O)OCC</smiles>

$\underline{2 c}$<smiles>CCOC(=O)C1=C(C)COC1c1ccc2c(c1)OCO2</smiles>

$\underline{2 c^{\prime}}$
Eq. 3 
Table 2. Electrochemical intramolecular cyclisation of $\underline{1}(12 \mathrm{mM})$ catalysed by $[\mathrm{Ni}(\mathrm{tmc})]^{+}$ in $\mathrm{EtOH}$ at a carbon fiber cathode containing $\mathrm{Et}_{4} \mathrm{NBr}(6 \mathrm{mM}) . \mathrm{j}=0.15 \mathrm{~A} \mathrm{dm}^{-2}$.

\begin{tabular}{|c|c|c|c|c|c|}
\hline Entry & Substrate & {$[\mathrm{Ni}(\mathrm{II})] / \mathrm{M}$} & Anode & $\begin{array}{l}\text { Products } \\
\text { (ratio of } \\
\text { isomers) }\end{array}$ & $\begin{array}{c}\text { Yield of } \\
\text { cyclised } \\
\text { products, \% }\end{array}$ \\
\hline 1 & $\underline{1 \mathbf{a}}$ & 2.4 & $\mathrm{C}$ & $\frac{\mathbf{2} \mathbf{a}}{\left(88: \frac{\mathbf{2} \mathbf{a}^{\prime}}{12)}\right.}$ & 91 \\
\hline 2 & $\underline{1 \mathbf{a}}$ & 1.2 & $\mathrm{C}$ & $\frac{\mathbf{2} \mathbf{a}}{(77: 23)} \frac{\mathbf{2} \mathbf{a}^{\prime}}{\mathbf{2} 3)}$ & 94 \\
\hline 3 & $\underline{1 b}$ & 2.4 & $\mathrm{C}$ & $\frac{\mathbf{2 b}}{(75: 25)}^{(\mathrm{a})}$ & 81 \\
\hline 4 & $\underline{1 b}$ & 1.2 & $\mathrm{Pt}$ & $\frac{\mathbf{2 b}}{(69: 31)}^{(\mathrm{a})}$ & 73 \\
\hline 5 & $\underline{1 c}$ & 2.4 & $\mathrm{Pt}$ & $\frac{\mathbf{2 c},}{(69: 31)}$ & 81 \\
\hline
\end{tabular}

${ }^{(a)}$ Diastereomeric (cis-to-trans) ratio.

\section{Conclusions}

(i) The experimental results presented suggest that the catalytic electroreductive cyclization of the bromoesters can afford cyclic compounds by constant current electrolysis performed in an undivided cell in the absence of sacrificial anodes; (ii) the yields of the cyclic esters are good enough to make this procedure an alternative to other synthetic methods; (iii) an advantage of this method is the radical reactions can be carried out using a catalytic amount of a complex of an appropriate metal at room temperature by an environmentally friendly methodology.

\section{Acknowledgments}

We are grateful to Fundação para a Ciência e Tecnologia for financial support of this work, Project $n^{\circ}$ F-COMP-01-0124-FEDER-022716 (Ref ${ }^{a}$ FCT PestC/QUI/UI=686/2011) FEDER-COMPETE-FCT-Portugal.

\section{References}

1. B. Giese, "Radicals in Organic Synthesis: Formation of Carbon-Carbon Bonds", Pergamon Press, Oxford (1986).

2. J. Fossey, D. Lefort, J. Sorba, "Free Radicals in Organic Chemistry", Wiley, New York (1995).

3. E. Dunach, M.J. Medeiros, S. Olivero, New J. Chem., 30, 1534 (2006).

4. Duñach E., Esteves A. P., Medeiros M. J., Olivero S., Green Chem., 8, 380 (2006).

5. K. L Vieira, D. G. Peters, J. Electroanal. Chem., 196, 93 (1985).

6. J. Chaussard, J. C. Folest, J. Y. Nédèlec, J. Périchon, S. Sibille, M. Troupel, Synthesis, 5, 369 (1990). 